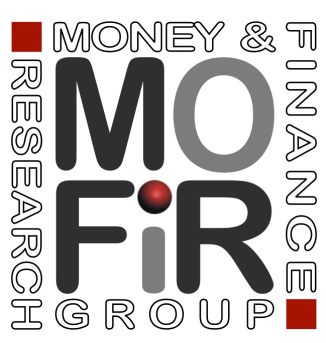

FIRM AGE AND THE PROBABILITY OF PRODUCT INNOVATION DO CEO TENURE AND PRODUCT TENURE MATTER?

Marco Cucculelli

Working paper no. 140

August 2017 


\title{
Firm age and the probability of product innovation Do CEO tenure and product tenure matter? ${ }^{1}$
}

\begin{abstract}
This paper examines the influence that the age of a firm has on the probability of product innovation by taking into account two factors: the role of the CEO's tenure and the lifecycle of the last product introduced. In a sample of Italian manufacturing firms ( $n=2,163$ ), analysis reveals that the new entrants' high innovative activity is mainly driven by the new CEO's innovation propensity, which is strictly dependent on his tenure. Likewise, the lower innovation activity observed in mature firms is mostly explained by the dynamics of the product's lifecycle and the CEO's tenure. More generally, the existence of a negative relationship between innovation and firm age is questioned, as controlling for time-related variables that overlap during the company's lifecycle - product age and CEO's tenure - turns the relationship positive. Finally, the innovative behaviour of incumbent companies turns out to be dependent on the renewal abilities of newly appointed external CEOs, whereas, CEOs from within the family play a minor role.
\end{abstract}

Keywords: Product innovation, firm age, CEO tenure, product tenure, product lifecycle, industry lifecycle

JEL Codes: D22, G34, L25, O32

\section{Forthcoming in Journal of Evolutionary Economics}

\footnotetext{
${ }^{1}$ I am grateful for comments and suggestions to Alex Coad, Jacob Holm, Elena Huergo, Jackie Krafft, Christian Le Bas, Tommaso Minola, Alessandro Sterlacchini, Francesco Quatraro, seminar and conference participants at the Conference "The Governance of a Complex World"- 18-20 Jun 2014, Collegio Carlo Alberto, Turin (Italy), ICSB 2015 Conference in Dubai and SIEPI 2015 in IULM Milan. Usual disclaimer applies.
} 


\section{Introduction}

The probability of introducing new products according to the firm age is a crucial topic in industrial economics, as it sheds light on the dynamics of industries and firm lifecycles (Huergo \& Jaumandreu, 2004; Malerba, 2006; Agarwal and Gort, 2002; Sutton 1997). Following an established line of empirical research, Huergo \& Jaumandreu (2004) (henceforth HJ2004) show that the likelihood of product innovation changes along the firm life. In their findings, a downward sloping line connects the probability of innovation (i.e., the introduction of new products) to the firm's age: young firms are prone to innovate, whereas the older ones propend to innovate less than the entrants. However, these findings only fit entrants, i.e. firms that have entered the market within 15-20 years, and mature incumbents, i.e., firms older than 35-40 years. In the case of firms aged 20-40 years, the probability of innovation appear to be, to some extent, positively associated with firm age.

$\mathrm{HJ} 2004$ explain this evidence as the outcome of a potential selection effect, as either good innovators do not exit the market in the first decades of their lifecycle, or surviving firms belong to markets with a special propensity to innovate. However, other variables are likely to affect the probability of innovation in firms of intermediate age, i.e., those between 20 and 40 years old. The purpose of the present study is to show that the splitting up of a firm's age into different and mostly overlapping components may help to explain the changes in the likelihood of innovation observed in incumbent firms over time. The basic idea consists in modelling the product innovation-firm age relationship not only including the firm's age, but also considering the influence on the decision to introduce a new product of two other time-related variables: product age (tenure) and the tenure of the chief executive officer (CEO). 
These three different - but inter-related - types of ages may have different impacts on the likelihood of product innovation, and make the age-innovation relationship significantly non-linear, as they are differently associated with the innovation process. As for age of the firm, Coad and colleagues (2014) state that "high performance firms have specific innovative capabilities that take time to accumulate, are difficult to copy, and enable firms to consistently introduce new and improved products and services" (Coad et al., 2012; 2013). This evidence, which is consistent with major findings from the resource-based theory (Barney, 1991; Penrose, 1959), points to firm age as a proxy for the ability of the company to develop and accumulate resources and competences and, in turn, generate new waves of products. Similarly, the age of the last product introduced in the product portfolio (product tenure) mirrors the firm's learning ability at the product level (Schoot, 2004; Bernard et al., 2010). This can be even significantly different from organisational learning and, more generally, it summarises the dynamics of the product lifecycle conditional on the structure of the existing product portfolio (Agarwal and Gort, 2002; Bernard et al., 2010). Finally, the "tenure" of the CEO, i.e., the time elapsed since the last change of CEO, summarises the impact of the renewal abilities of the new CEO on the innovative performance of the company (Miller, 1991; Miller \& Shamsie, 2001; Levinthal \& March, 1993; Kuratko and Audretsch, 2009).

By integrating a unique dataset on product innovation and firm governance with company accounts over the period 2000-2010, this article shows that the likelihood of product introduction does not always decrease with the age of the firm. The negative innovation-age relationship found in other studies, and at first glance observed also in this dataset, turns positive when a product's lifecycle and the CEO's tenure are taken 
into account. Specifically, we find that incumbents are not poorer performers than new firms in introducing a new product when the CEO's tenure and the product's tenure are properly taken into account within the basic firm age-product innovation relationship.

This study makes three contributions to literature. First, it supports the hypothesis that the likelihood of innovation in firms of intermediate age (i.e., those aged 20-40 years) may depend on the changes in the governance structure over time and on the dynamics of the product portfolio. When the impacts resulting from CEO changes and product lifecycle are taken into account, the non-linear relationship between a firm's age and product innovation weakens significantly, and its slope becomes positively oriented. Second, the innovation activity of young firms is significantly affected by the innovation propensity of short-tenured CEOs and by the influence of short product lifecycles, especially when companies operate in very innovative markets. Controlling for these two variables permits to explain a significant part of the innovative activities of new entrants, as well as the poor innovation propensity in mature companies managed by long-tenured CEOs. Third, as product innovation and CEOs' succession interact throughout the company's lifetime, the time interval between these two events comes out as a predictor of the innovation activity. In this framework, a short-tenured CEO emerges as the most valuable driver of the innovation activity of the company, with a more important role for external CEOs than family CEOs.

The rest of the article is organised as follows. Section 2 summarises the literature background of the study. Section 3 presents the empirical analysis, which includes the data and empirical model. Section 4 briefly discusses the role of the product 
innovation-CEO succession time gap in explaining the probability of innovation, and Section 5 concludes the paper.

\section{Product tenure, CEO tenure and innovation}

The traditional perspective on firm growth treats each firm as producing a single product and being run by the same entrepreneur (Kirchhoff, 1994; Goldberg et al., 2009; Stam, 2007). The micro-econometric evidence based on this approach has two major drawbacks ${ }^{2}$. On the one hand, it fails to consider the multiproduct nature of the growth process and neglects the dynamic structure of the activity of product innovation. Over time, firms create additional innovations and focus on generating a continuous stream of products as a means to achieving growth: "the process of innovation and entrepreneurship are one and the same only when the process is carried out by a small firm early in its life" (Kirchhoff, 1994; p. 62). On the other hand, it fails to take into account the change of the entrepreneurial orientation of the company that occurs because of change of the CEO (Miller 1991), and that influences the probability of product innovation over time. As both product lifecycle and tenure of CEO come out as crucial components of the decision to introduce a new product, I will briefly deal with these two variables in the following sections.

\subsection{Product age and product innovation}

It is well recognised that a firm's innovative activity can be proxied by the release of a new product (Giulioni, 2011). New products summarie the innovation

\footnotetext{
${ }^{2}$ A notable exception to this pattern are the recent studies by Bernard, Redding and Schott (2010) and Goldberg et al (2009), that suggest that product mix changes represent a potentially important channel through which firms grow by moving resources from less to more efficient uses within firms.
} 
ability of firms that consists of searching, identifying and evaluating alternative knowledge from different sources. After this search, the company transforms the knowledge into specific products that constitute the product innovation (Danneels, 2002; Zhou and $\mathrm{Wu}, 2010)$. Accumulation of knowledge is mainly the result of purposeful investments (Kueng, et al., 2014), and products are a measure of the knowledge accumulated by the firm during its lifetime. If a firm is a sum of products for which a particular innovator has found the most productive technology, an older firm is more likely to innovate since it has accumulated more knowledge. Klepper (1996), Klette and Kortum (2004) and Akcigit and Kerr (2010) emphasise that older firms concentrate on non-radical innovations that exploit existing knowledge, whereas younger and smaller firms are more likely to generate product innovations. Therefore, product innovation intensity is expected to decline with age.

When we assume multiproduct firms, the firm's age and the product's age can vary greatly, and the firm's age may not be sufficient to represent the specific knowledge incorporated in a single product. This explains why the extant empirical literature on the impact of product innovation on a firm's performance often failed to find a robust correlation, as it mostly overlooked the call for a more fine-grained analysis of the product portfolio composition (Becheikh et al., 2006).

In this context, the tenure of the latest new product, i.e., the years passed since the launch of the product in the market, is more revealing (Cucculelli and Ermini, 2012). Product tenure is a crucial variable in understanding the innovative propensity of a firm, as it is able to capture the position of the product in its lifecycle, or other characteristics of the new product, such as its novelty and complexity. Recent evidence found in the literature on product lifecycle, shows that different stages of the lifecycle 
are characterised by very different cost and price conditions, as well as different consumer sensitivities to price and, in turn, product acceptance (Golder and Tellis, 2004).

Besides assessing the existence of the product's lifecycle, the tenure of the last product also proxy for other properties of the product that affect consumers' preferences and valuation: degree of newness, latest design, prestige or good reputation, product quality (Burgel et al., 2002; Schott, 2004; Bernard et al., 2010; Moral and Jaumandreu, 2007). Also, product tenure can account for heterogeneous attributes of products in terms of technological and economic value, which would otherwise be obfuscated under the mere count of (potentially) highly differentiated new products (Tether, 1998; Loof and Heshmati, 2006; Schott 2004; Moral and Jaumandreu, 2007).

Controlling for the tenure of the last product is also useful to take into consideration the degree of newness and complexity of the product portfolio (Cefis and Marsili, 2011; Loof and Heshmati, 2006). Some new products are characterised by short product lifecycles, as in the case of market-driven innovations that are required by the market (Barlet et al., 2000), or innovations in hightech industries, where old products signal out-of-date and superseded designs (Klepper, 1996; Burgel et al., 2002; Gopalakrishnan and Bierly, 2006). On the contrary, very innovative products may be accepted by the market at a slow pace (Barlet et al., 2000), thus making the product's lifecycle curve longer and shifted rightwards, with a startup phase abnormally extended, and a growth phase delayed in time. Besides, network externalities on the demand side may further shift the product lifecycle curve rightwards, and lengthen the 
time taken for new products to reach maturity (Klepper and Graddy, 1990; Economides, 1996; Das, 1995).

To sum up, if new products express the firm's updated technical and market capabilities that have turned into profitable goods (Geroski, 2005; Geroski and Mazzucato, 2002; Danneels, 2002; Deeds, 2001; Cohen and Levinthal, 1990; Geroski et al., 1997), product tenure plays a crucial role to proxy for the learning abilities of the company at product level (Bernard et al., 2010).

\subsection{Organisational age, CEO age and innovation}

Several studies have examined the way in which age influences strategic choices and company performance over time (Jovanovic, 2001; Levesque and Minniti, 2006; Marshall et al., 2006; Sorensen and Stuart, 2000). This literature shows that firms do not perform uniformly over their lifecycle. On the one hand, experience fosters a firm's performance, as competence-enhancing activities implied by ageing favour the implementation of established routines (Acemoglu et al., 2006), or allow firms to better recognise and exploit new technological opportunities (Cohen and Levinthal, 1990). On the other hand, ageing can negatively affect a firm's performance because of inertia (Miller and Shamsie, 2001). Success induces firms to codify their approach with proper organisation and processes: this may increasingly entrap firms in structural and process-related rigidities that are difficult to drop (Leonard-Barton, 1992), and induce them to ignore the innovation signals from the marketplace (Agarwal and Gort, 2002).

For a long time, economists have considered the impact of the process of organisational ageing on firms' behaviour. Reinganum (1983) shows that an incumbent 
may not be interested in investing in new product development, because if it succeeds, it would merely strengthen its market position. Marshall et al., (2006) show that as managers grow older, they become more reliant on their own sources of information for making decisions, more conservative and less likely to take risks. Jovanovic (2001) argues that older owners and managers may become progressively less aligned to external conditions as these move away significantly from their fields of expertise. Grossman and Shapiro (1982) model a choice of specialisation that may lead the firm into a "competency trap", in which the accumulation of production experience exacerbates the decline in the organisation-environment fit. Sorensen and Stuart (2000) argue that over time, firms may become better at performing routines that are increasingly less valued by the environment, thus deteriorating the organisationenvironment fit and company performance.

On the other hand, ageing may benefit performance if it allows firms to better recognise and exploit the potential of new technological opportunities in related areas (Cohen and Levinthal, 1990; Rubenson et al., 1996), or benefit from the previous competence-building activities (Abernathy and Utterback, 1978; Sorensen and Stuart, 2000). Furthermore, competence-enhancing activities implied by organisational ageing may favour a cumulative effect of established routines, thus increasing the appeal of the existing courses of action (Stinchcombe, 1965). Finally, organisational age could play a crucial role when industries vary in the degree to which a firm's performance is determined by "learning-by-doing" (Balasubramanian and Lieberman, 2010), or other opportunities of active learning (Geroski, 1995; Jovanovic, 1982; Ericson and Pakes, 1995). However, despite the extensive research, the impact of organisational age on innovative performance is still controversial. 
The literature on CEO tenure and CEO lifecycle is more revealing. Miller and Shamsie (2001) show that tenure (and experience) may initially boost the firm's performance, as externally hired CEOs have competencies that are aligned with environmental conditions, and they possess clear ideas about how to manage their role. Then, eventually, they may become overly committed to the earlier formulae, and find it difficult to execute new plans. This causes their performance to decline with tenure (Miller, 1991). In addition, ageing may also lead entrepreneurs to become averse to uncertainty, which makes them careful in taking the effective entrepreneurial decisions they once took (Van Praag 2003).

From a strategy viewpoint, CEO's tenure is indicated as being the most important antecedent for strategic changes, a feature that includes the decision to introduce a new product (Karaevli \& Zajac, 2013; Finkelstein, Hambrick \& Cannella 2009; Quigley \& Hambrick, 2012; Miller, 1991; Miller \& Shamsie, 2001) $)^{3}$. As longtenured CEOs increasingly narrow their perspectives and become less open minded, firms led by long-tenured CEOs may continue to follow the existing directions, and strategic changes are most likely to occur when a new CEO is appointed (Quigley \& Hambrick, 2012; Miller \& Shamsie, 2001). Also, long-tenured CEOs tend to refine their existing knowledge, whereas short-tenured CEOs learn and develop new skills (McClelland, Liang, \& Baker, 2010). Novel product designs, fresh marketing campaigns, and new strategic directions are more likely during these early stages, which are essentially exploratory in nature (Levinthal \& March, 1993). Moreover, short-tenured CEOs are found to generate greater technological output, suggesting that CEOs with a

\footnotetext{
${ }^{3}$ Changes in the structure and composition of the product portfolio are among the most relevant strategic changes a new $\mathrm{CEO}$ is expected to bring on.
} 
short tenure are more likely to explore new possibilities and introduce innovation ( $\mathrm{Wu}$, Levitas and Preim, 2005).

In line with the positive influence that short-tenured CEOs have on innovation, CEO succession has often been indicated as a crucial variable to explore innovation. As an inertia breaker, CEO turnovers provide a periodic opportunity for organisations to break out of their inertial paths (Karaevli \& Zajac, 2013; Pfeffer and Salancik, 1978), and to amplify the likelihood of change (Miller, 1991). Also, company management improves over time as new generations of motivated CEOs join the company and adopt superior managerial tools and practices (Bloom and Van Reenen, 2008), or bring into the company new resources and competencies. This may sustain strategic renewal and lead to product innovation (Quigley \& Hambrick, 2012; Fernández and Nieto, 2005).

Finally, the impact of management change on performance may also depend on the type of governance structure of the firm, with family owned and managed firms achieving different performances than professionally managed firms (Miller et al., 2007; Anderson and Reeb 2003; Villalonga and Amit 2006; Bertrand and Schoar 2006). Proponents of internal successions (family CEOs) stress that the family CEOs have greater knowledge of the firm, and their established social networks (Chung et al., 1987; Chua et al., 2003), thus providing a smooth transition and stability. On the contrary, outside CEOs are generally suggested as a remedy for a company's difficulties: when drastic changes are required, external managers appear to be more promising because they are not bound by old policies and implicit contracts of the firm, especially when an organisation performs poorly and needs a "change agent" (Chung et al., 1987; Hambrick and Mason (1984). 


\section{Empirical analysis}

\subsection{Methodology}

This paper follows the empirical approach developed by HJ2004a. It links the likelihood of introducing a new product to the age of a firm, and estimates (crosssection/over time) the following probability model (HJ2004a):

$$
P\left(y_{i t}=1 \mid x, \tau\right)=E\left(y_{i t}=1 \mid x, \tau\right)=x_{i t} \beta+\vartheta\left(\tau_{i t}\right)
$$

where $y$ is a dummy variable indicating product innovation, $x$ is a vector of control variables, which includes product tenure and CEO tenure, $\tau_{i t}$ is the age of the firm, and $\vartheta$ is an unknown function linking probability to the firm's age. Table A1 in the Appendix presents a list and a description of variables.

\subsection{Data}

The dataset has been built by matching two complementary sources: a crosssectional survey $(n=2,163)$ collected directly from companies through a questionnaire-based interview, and a dataset with financial data available from the year 2000 to 2010 from AIDA - Bureau van Dijk. ${ }^{4}$

\footnotetext{
${ }^{4}$ The AIDA - Bureau van Dijk DATABASE is an authoritative and reliable source of information on Italian companies. Information is drawn from the official data recorded at the Italian Registry of Companies and from the financial statements filed at the Italian Chamber of Commerce. Companies furnish data on a compulsory basis. The information provided includes company profiles and summary of the financial statements (balance sheet, profit and loss accounts, and ratios). Each company's financial statement is updated annually. Additional information on the AIDA Bureau van Dijk database can be obtained from http://www.bvdinfo.com.
} 
For the survey, we selected a large set of non-farm, non-service companies in the Italian manufacturing sector. The survey was restricted to four Italian regions that shared some common features in the organisation of the industry. The major industry specialisations included: (1) mechanical industry; (2) fashion (clothing and footwear); (3) wood and wooden furniture; and (4) manufactured plastic products.

The survey gives information on three areas: (1) firm's age; (2) the structure and characteristics of the product portfolio, i.e., the number of products in the portfolio, the year each product had been introduced and its detailed code of classification (five-digit Nomenclature of Economic Activities (NACE) classification); and (3) the CEO's tenure and his/her type (family or external).

The product innovation variable indicates a major change in the product portfolio of a company, and implies a significant renewal of a firm's technological and commercial capabilities (Danneels, 2002). We followed Bernard et al., (2010) by considering as a new product one with a different five-digit NACE-Ateco (SIC) category from products in the rest of a firm's portfolio. We do not take into consideration small refinements or negligible enhancements in product features. ${ }^{5}$ As for the CEO, we included in the definition all the persons "in charge of the major decisions" as indicated by the company: CEO, or alternatively the President /Chairman of the board, the Executive Director, the CFO/COO or other senior executive when a CEO was not present. $^{6}$

\footnotetext{
5 Compared to other definitions in the empirical literature (e.g. new product announcements, refinement or restyling of existing products, quality or design improvements, and other marginal changes), this stricter definition of a new product might actually underestimate the true impact of product innovation.

${ }^{6}$ In case of two or more CEOs, we only considered the one with the longest tenure. The addition of a new CEO to an existing board has not been considered a CEO change.
} 
The product tenure indicates the age of the last marketed product. The variable has been computed as the logarithm of the number of years between the current year " $\mathrm{t}$ " of the panel and the year " $\mathrm{t}$ " representing the introduction of the last product which entered into the firm's product portfolio, with $t^{*}<t$ (Cucculelli and Ermini, 2012). Similarly, the CEO's tenure indicates the duration of CEO employment with a given company, and is computed as the difference between the survey date and the date when the CEO was hired.

\subsection{Summary statistics}

Statistics for the complete sample, broken down by region, industry and other relevant variables, are summarised in Table 1 . The largest share of firms is in the metal-mechanical industry, which accounts for $48.2 \%$ of the sample firms, whereas the traditional sectors (food, textile and clothing, footwear, wood and furniture) account for about $37.6 \%$. Almost three firms out of four have less than 50 employees. The firm age distribution presents a large share of firms born between 1970 and 1990 (about 65\%), whereas the share of firms born before 1970 is $14.7 \%$. Figure 1 ( Panel A) presents the distribution of firms by age, and compares the distribution in this sample with the HJ2004a sample.

[Table 1 about here]

[Figure 1 about here]

The distribution of innovative firms, that is, firms that have introduced at least one new product, shows that older firms have a high propensity to innovate, as the 
share of innovative firms born before 1980 (64.7\%) is higher than the share of firms of the same age in the sample (45.0\%). Figure 1 (Panel B) presents the distribution of the product tenure and the CEO's tenure. Besides the large share of new products of less than 3 years, the product tenure presents an inverted U-shaped distribution, with a modal class at 22-24 years, and a noticeable decrease in the frequency of older products. The CEO's tenure peaks in the period of 8-10 years, and then declines significantly.

\subsection{Descriptive statistics on product tenure and CEO's tenure}

Figure 2 (Panel A) displays kernel estimates of the relationship between product innovation and the tenure of the last product introduced. The high propensity to innovate associated with a short tenure of the last product ( 0 to $8-10$ years) suggests the presence of short product lifecycles because of very competitive markets or highly innovative industries. After a decline of up to 15 years, the propensity to introduce new products rises again: this evidence is consistent with a lifecycle model where the growth phase of the product peaks at around 20 years, followed by maturity and the introduction of a new wave of products. Figure 2 (Panel B) describes the relationship between the introduction of a new product and the CEO's tenure. This relationship monotonically decreases with the CEO's tenure, with a propensity that weakens moderately after the 10th year, and then declines significantly for very long tenures. Taken together, these pieces of evidence show that product tenure as well as the CEO's tenure may be potential predictors in the decision to introduce a new product.

[Figure 2 about here] 


\subsection{The role of industry}

\subsubsection{Industry lifecycle}

Lifecycles of industries affect the characteristics of demand and the rate and form of technical change (Agarwal and Gort, 2002; Malerba, 2006; Krafft \& Ravix, 2008). As the market evolves to maturity, technological opportunities decline and innovation progressively shifts to minor product refinements and cost reduction (Karlsson \& Nystrom, 2003). Also, competition intensifies as the competitive focus is on imitation rather than pure innovation, as in the infancy phase of the industry's lifecycle (Karniouchina et al., 2013). Most importantly, the distribution of new product innovations between new and incumbent firms may change over the lifecycle, with consequences for the innovation probability of different cohorts of firms (Agarwal and Gort, 2002; Krafft, 2004). Finally, the propensity of product innovation may be consistent with a highly recursive view of the industry's lifecycle, where transitions are not unidirectional from earlier to later phases, but oscillate back and forth mainly between growth and maturity, suggesting that industries are successful at renewing the lifecycle prior to decline (Karniouchina et al., 2013). All these considerations stress the importance of control for the phase of the industry's lifecycle in the decision to introduce a new product. Table 2 and Figure 3 present probabilities of product introduction and kernel regression of product innovation by the industry phase. Lifecycle phases have been computed using the data on entry and exit in the Italian manufacturing industry for the period 1995-2010. A total of 22 sectors (2-digit NACE) have been considered: this is the finest disaggregation allowed by data on the business 
demography of the Italian manufacturing industry ${ }^{7}$. Phases have been identified as those time intervals for which the definition of Agarwal and Gort (2002) applies, and is measured on the basis of the gross business entry rate per year. The phases reported in Table 2 and Figure 3 are: (1) initial low entry; (2) increasing entry rate; (3) decreasing, although still high entry; (4) low entry; and (5) erratic pattern of gross entry which characterises the maturity of the lifecycle. The propensity of product innovation is significant in lifecycle phase 1 (initial low entry), peaks in phase 2 (increasing entry rate), and then declines progressively in the maturity and decline phases (Figure 3). Industry lifecycle associates closely with the innovation activity at the industry level, with product innovation clearly concentrated in the early phases of industry evolution. Also, the mean values of a firm's age by phase (see Table 2) show that mature firms are also present in the early phases of the industry's lifecycle, thus suggesting that these firms are active innovators even among new industries.

[Table 2 about here]

[Figure 3 about here]

\subsubsection{Technological intensiveness}

While the intensity of competition is captured by the lifecycle phase, industries also vary in technological intensiveness (Agarwal and Gort, 2002). To take this aspect into account, we rely on the distinction between firms that operate in Industry of Manufacture (IOM) sectors and in Sectors of Use (SOU) sectors, as illustrated by the

\footnotetext{
${ }^{7}$ Appendix 3 reports a robustness test for the impact of different controls for the industry effect on product innovation regressions.
} 
OECD Technology Concordance Report (Johnson, 2002). ${ }^{8}$ The IOM group includes those sectors whose patenting rate is higher than the median score of the total industry distribution, that is, patent-producing sectors (Johnson, 2002). Firms in this sector have proved to be efficient in the inventing activities, but they are not as efficient as the innovators, or their patents have scarce business value. Conversely, the SOU group includes those sectors that mainly use patents produced by other sectors: if firms in these sectors decide to bear the cost of patent acquisition, they are likely to see good prospective commercial exploitation.

\subsubsection{Industry demand}

In addition to the role played by the industry lifecycle and technological intensiveness, short-term trends in the industry demand may be crucial drivers of the decision to introduce a new product (Woerter, 2009). Industry demand - as proxied by the aggregate industry turnover - is an ideal candidate to control for the role of external conditions on firm-level decisions, as it affects individual firms, but is, to a large extent, beyond the control of individual firms. As a proxy for the sectoral industry demand, we used the Eurostat Annual Turnover Index, which is a business cycle indicator provided by Eurostat. It records the evolution of turnover over long periods of time, and measures the market activity in the industrial sector in value. The industry breakdown is done by 101 3-digit NACE sectors, and the indicator is split into the Domestic Turnover Index (DTI) and Foreign Turnover Index (FTI). Mean values and

\footnotetext{
${ }^{8}$ The OECD Report (Johnson, 2002) separately maps patent categories into the economic sectors responsible for their creation (IOM index) and their subsequent use (SOU index). Although IOM represents the innovative activity within each sector, the SOU index measures the share of the total patents that are used in each sector, regardless of whether it is the sector that produced the patent. The OECD index is calculated by classifying the patents (by nationality of the applicant) for six major applicant nations - including Italy — in the EPO database in 1998.
} 
correlations for all the variables included in the empirical analysis are reported in Table 2 in the Appendix.

\subsection{Empirical results}

The results of the estimates are presented in Tables 3 and 4 and in Figure 4. Estimates in Table 3 include time, industry and size dummies, the size of the product portfolio (number of products), and a dummy for the stock of patents. Table 4 reports the impact on the propensity of product innovation of the two variables of interest, i.e., product tenure and CEO tenure.

\section{[Table 3 about here]}

Table 3 presents the results of the estimation on control variables using the Suits method (Suits, 1984). Time dummies reflect the effect of the absence of a relevant year effect in the decade. As for the firm's size, product innovation is significant in smaller and in medium-sized firms, whereas larger firms appear to be less innovative. Patenting is positively associated with product innovation, as firms with no patents show a low likelihood of introducing a new product, and a larger stock of patents correlated with a higher propensity to innovate (Le Bas \& Poussing, 2012). However, despite being positive for all patent classes, the likelihood is significant only for the class of firms with one patent, thus suggesting the existence of a close relationship between patents and the introduction of new products. Also, this evidence is consistent with the assumption that patents are more effective in supporting incremental innovation rather than new products in multipatent companies. The range of probability differences ascribed to patents is sizeable (0.179), 
and it is almost completely due to the patenting status of the company, i.e., firms having one patent versus firms having none. As for the product portfolio, the probability of innovation increases with the size of the existing product portfolio, thus suggesting that scale economies in the management of product portfolio may exist, or that organisational learning in product introduction helps innovation over time. Finally, industry dummies show that the most innovative sectors are rubber and plastic, industrial machines, other transportation vehicles (yachts in particular), and miscellanea (toys and furniture). The differences in the probability of product innovation between sectors ranges from -0.05 for printing to 0.17 for other vehicles. The range between extreme values reaches a 22-percentage point, which is in line with the HJ2004a results.

Figure 4 reports the kernel regression of the conditional expectation function of model (1) that links the innovation probability to the age of the firm. First and foremost, the changes in the likelihood of product innovation over the lifecycle are sizeable and significant: a declining trend is observed until 18-20 years, then a net increase and a peak at about 30 years, followed by a decline from 35 years onwards. Organisational age does appear to be a significant component of the heterogeneity of innovation activity, and a driving force behind the non-linearity in innovative behaviour by age. Second, the range of probability values by age reaches a 12-percentage point (8-percentage point in the $\mathrm{HJ} 2004 \mathrm{a}$ article), a large part of the overall variation in the average probability. Third, young firms appear to have a high probability of innovation, which declines constantly in the post-entry period and increases again after about 15 years. Also, the innovation activity drops significantly in the last period of the age domain (35-60 years), whereas firms aged 20-35 years appear to be as innovating as 
new entrants, or even better. Thus, the trend observed by HJ2004a is confirmed also in this sample, with negligible variations in the time profile of the relationship probably due to sample composition and the use of different control variables. Fourth, the distance between the likelihood of innovation when the firm first enters the market and its peak value is about $11 \%$, which is slightly lower than the HJ2004a's estimate (15\%), most likely explained by our underestimation of the innovative activity in very young firms because of the lack of control for exiting firms.

[Figure 4 about here]

Figure 4 also provides a comparison with HJ2004a's findings. The shapes of the two curves are almost similar in the relevant domain. Also, after a marked rise from $15 / 20$ years and a constant decline thereafter, the likelihood of product introduction peaks around 30 years in the two curves. The most notable difference in the two samples is in the 10-year post-entry period, during which the innovation activity slightly increases in the HJ2004a sample and decreases in this sample.

Table 4 presents results of the estimates of the firm's age-innovation relationship. All control variables included in Table 3 have been taken into consideration also in Table 4, together with controls discussed in Section 3.5. To overcome limitations due to the sample size, all controls have entered the estimating equations parametrically, including the dummy variables constrained to add up to zero in the previous estimates in Table 3 (Suits, 1984). Column 1 reports the estimate of the basic model with the firm's age entering as a continuous variable. The variable presents a negative - even not significant - coefficient on the propensity for innovation (the coefficient is significant only when the full set of controls is not used: 
$b=-0.11^{* *}$ [s.e. 0.05]). As far as controls are concerned, later phases in the industry's lifecycle, i.e., maturity and decline, lead to reduced activity in product innovation. The decline in the likelihood of innovation along the industry lifecycle is statistically significant, and makes it necessary to take into account the industry attributes that affect innovation both over time and across markets. The innovation rates are significantly higher in the IOM sectors, i.e., patent-producing sectors. Conversely, sectors in the SOU group, i.e., sectors that mainly use patents produced by some other sectors, show a low and non-significant relationship with the product innovation activity. Also, short-term trends in industry demand - as proxied by the industry turnover - affects an individual firms' probability to introduce a new product, but only in the case of foreign demand (Foreign Turnover Index). The number of products in the portfolio positively affects the probability of product innovation, thus showing the presence of scale economies in the management of larger product portfolios, even if the relationship turns negative when a control for product tenure is introduced in the regression. Finally, the number of patents has a positive impact on the probability of introducing new products, whereas firm size (number of employees) negatively affects the estimated relationship.

[Table 4 about here]

When age classes are used as explanatory variables, and both product and CEO tenures are not included as controls (column 2), firms appear to be most innovative when younger than 10 years. Then the innovation propensity decreases markedly in firms aged 10-19 years, and those older than 40 years. For the sample of firms between the ages of 20 and 40 years, the innovation probability is slightly lower than 
the baseline, but the difference is not statistically significant. Column 3 reports the estimated results when product tenure is included as a control: the variable enters the regression model with a quadratic specification to account for the non-linearity of the innovative behaviour by tenure. The coefficient for the tenure is significant and describes an inverse relationship between product tenure and product innovation in the relevant domain: this means that the lengthy tenure of a product is associated with a lower likelihood of innovation. The coefficient for the squared variable indicates that the negative trend tends to weaken when the old product is entering its maturity or declining phase, thus making the estimated relationship U-shaped. In sum, the inclusion of the product tenure changes the age-innovation relationship considerably: when product tenure is taken into account, all the coefficients of age classes turn positive, in particular, those in the age groups of $20-39$ years and $40+$. As a result, the high intensity of innovation associated with young firms reduces substantially when product tenure is accounted for, whereas the probability of innovation in mature firms comes out as significantly positive.

CEO tenure (Column 4) negatively affects the propensity for innovation in the sample firms, and its impact on the propensity of innovation is as strong as, or even stronger than, the impact of product tenure (the two distributions have comparable mean values). However, when CEO tenure is controlled for, a positive and significant impact on the probability of innovation by age class is observed for firms in the age class of 20-39 years, whereas the coefficient remains negative for the age class $40+$ years. In sum, the impact of CEO's tenure is significant only in the case of very young companies, or in older companies (20-39 years), where a CEO succession is more likely to occur. Finally, when product and CEO tenures are considered together (Column 5), 
the probability of innovation increase significantly in the age classes $20-39(b=0.129$, s.e. 0.058$)$ and $40+$ years $(b=0.106$, s.e. 0.054$)$, whereas the high innovation intensity in young firms appears to weaken.

Columns 6 and 7 of Table 4 report the estimates of the previous tenurecontrolled models with the Suits method applied to age classes. Estimated results generally confirm the previous findings: when product and CEO tenures are not controlled for, the innovation activity appears more intense in firms younger than 10 years, whereas firms in the age class $10-20$ years come out as weak innovators. On the contrary, the probability of innovation shows again a U-shaped relationship with the firm's age when the product and CEO's tenures are included in the model.

Finally, to look at the relationship between the firm's age and the slope of the innovation-tenure profile along the age distribution, an estimate of a spline function model has been run to see if an upward sloping relationship can be found in these data. The spline model has knots at the firm's age corresponding with the same kinks used in the estimates of age classes in the previous models $2-5$ : $0-9 ; 10-19 ; 20-39$; $40+$ years. Results basing on these specifications are presented in Columns 8 and 9, Table 4. As for product tenure (Column 8), the age-innovation relationship decreases in the first age interval of $0-9$, and then it increases significantly in the age interval of 10-19 years, and in the following intervals, even if at a slower pace. Consequently, controlling for product tenure makes the age-innovation probability upward sloping, although at a decreasing rate. As for the CEO's tenure (Column 9), a negative slope is estimated for the interval of 0-9 years, followed by positive and significant - albeit small - slope in the age class 10-19 years. In addition, a model has also been run using the firm's age on the date of product introduction (or CEO change). This different 
variable allows considering the potential bias due to differences between the firm's age distribution and the age distribution on the date of introduction of the new product or change of CEO (Brown and Medoff, 2003). Results on these specifications broadly confirm the estimated results reported in Table 4, Columns 8 and 9. ${ }^{9}$

Summing up, some conclusions can be drawn from the above results. First, when the high innovative propensity in the early stages of the CEO's career is considered, the of introduction of a new product shifts substantially downwards in the first period of the company's life. Therefore, a significant part of the innovative activity of young firms is likely to be ascribed to the contribution by new, short-tenured CEOs, who are very well versed in the external economic environment. Besides this, the tendency of new CEOs to innovate also drives the innovative activity in firms aged 2040 years, as the chance of being innovative does not decline when a control for the CEO's tenure is included. In firms that are aged 20-40 years, CEO succession is positive because new CEOs are able to introduce new ideas and to pursue new initiatives, which form the basis for the innovative activities of the company. This evidence is consistent with the temporal profile of the CEO's tenure distribution, whose mean and the median values are 27.6 and 29 years, respectively. Finally, the low innovative activity indicated by most literature in mature firms (aged 40 years or more) almost disappears when the CEO's tenure is controlled, thus providing new evidence to explain how inertia develops and hinders innovation in mature organisations (Miller, 1991). Second, when a control for the product tenure is added to the basic framework, a further significant drop in the innovative activity of young firms is observed. Both, the probability level and the slope of the relationship turn out negative for firms in the

\footnotetext{
${ }^{9}$ Estimation results are available upon request.
} 
first age interval. By explicitly taking into account the existence of short-tenured products (either new products in highly technological areas or unsuccessful product launches that make product tenure shorter), the likelihood of innovation drops significantly in the first part of a firm's lifecycle, after which it starts rising. As for the case of the CEO's tenure, there is a close association between the observed trend in propensity of innovation and the distribution of the product tenure variable, which has a median value of 22 years and the mean at 24 years. Finally, in mature firms, i.e., firms aged 40 years or more, both the level and the slope of the likelihood of innovation remain positively related to the firm's age, in particular, when controls for the product tenure are included.

To sum up, the probability of product innovation appear to be increasing with the firm's age when the roles of product and CEO tenures are considered. Younger firms appear to be less innovative when their innovation activities are controlled for the positive impact of a new CEO and the competitive conditions these firms face as entrants. On the contrary, older firms are more innovative than expected when the CEO's tenure and product lifecycles are taken into account. This evidence supports an upward-sloping curve between innovation propensity and the age of the firm.

\section{The CEO change-innovation time gap}

The empirical evidence in the previous section shows that the product lifecycle together with new CEO's propensity to innovate, and the old CEO's probable inertia (Barron et al., 1994), explain a significant part of the propensity for innovation in mature firms. If a firm's innovative performance during its lifecycle is affected by the overlapping trend of the CEO's tenure and product portfolio management, it is 
important to understand how innovation and succession interact during the company's lifetime, and how the time interval between these events affects the firm's innovative activities.

To this aim, a variable has been created to measure the time lag (in years) between the introduction of the new product and the CEO change. The variable has been termed "succession-innovation gap". Also, because of the different roles played by family CEOs and external CEOs in terms of the company's renewal ability, family and non-family successions have been considered separately. Table 5 reports the estimates of the probability of product introduction with a succession-innovation gap ranging from 1 to 10 years. When the total number of new product introductions after a succession (CEO change) is considered $(n=829)$, the results in Table 5 show that product innovation and succession are two events in the company's life that cannot be accommodated in a very short span of time. The introduction of a new product is hardly observed one year after the CEO change. However, the probability of product introduction becomes positive and significant three years after succession, and then declines gradually in the remaining 7-year period. The partition of the sample in family and external CEO succession is even more revealing. In the case of new CEOs appointed within the founding family, the probability to observe a new product introduction is flat along the entire period, despite positive - but not statistically significant - values from the 2 nd to the 6th year, and negative for the last 3 years. Conversely, the probability of innovation when external CEOs step into the company is significantly positive in the 2 nd to the 4 th-year period, after which it turns negative. Therefore, the positive short-tenured CEOs impact on product innovation appears to be driven mostly by external CEOs, who are able to support the innovative activity in 
the early stages of their tenure. Figure 6 presents evidence from a kernel regression consistent with this result, and shows that the contribution of external CEOs to innovation is significant and concentrated in the early season of their tenure.

[Table 5 about here]

[Figure 6 about here]

\section{Final remarks}

This article contributes to the literature on the dynamics of the probability of product innovation by age in incumbent firms. The main findings may be summarised as follows. The increase in the probability of innovation observed in firms aged $20-40$ years is largely explained by variables related to the CEO's tenure and to the lifecycle of the last product introduced. Also, the new entrant's high innovative activity rests on the new CEO's propensity for innovation, which is strictly dependent on the CEO's tenure, whereas the declining innovation activities of mature firms almost disappears when the role of the product lifecycle and inertia of the long-tenured CEOs are considered. Overall, the existence of a general negative relationship between innovation and the firm's age is questioned, as the presence of different "ages" in the company's life - i.e., product age and CEO tenure - makes the relationship positive. Finally, the innovative behaviour of incumbent companies appears to be dependent on the renewal ability of newly appointed CEOs who come from outside the company, whereas the role of family CEOs appears less important for the innovative activities of the firm. 


\section{References}

Acemoglu, D., P. Aghion, C. Lelarge, J. Van Reenen, and F. Zilibotti (2006). Technology, Information and the Decentralization of the Firm, NBER Working Paper No. 12206.

Agarwal, R. and Gort M. 2002. Firm and Product Life Cycles and Firm Survival. American Economic Review, 92(2): 184-190.

Akcigit, U. and Kerr W. 2010. Growth through Heterogeneous Innovations, NBER Working Paper No. 16443.

Anderson, R.C. and. Reeb. D.M. 2003. Founding-Family Ownership and Firm Performance: Evidence from the S\&P 500. Journal of Finance. 58:3, pp. 1301-28.

Balasubramanian N., Lieberman M.B., 2010, Industry learning environments and the heterogeneity of firm performance, Strategic Management Journal, 31: 390-412 (2010)

Barlet, C., Duguet, E., Encaoua, D., Pradel, J., 2000. The Commercial Success of Innovations: An Econometric Analysis at the Firm Level in French Manufacturing, in: D. Encaoua et al. (eds), The Economics and Econometrics of Innovation, Boston: Kluwer Academic Publishers, pp. 435-456

Barney J. 1991. Firm Resources and Sustained Competitive Advantage, Journal of Management, March, vol. 17 no. 1 99-120

Barron, D. N., E. West, and M. T. Hannan. 1994. A Time to Grow and a Time to Die: Growth and Mortality of Credit Unions in New York, 1914-1990. Am. J. Soc.100:381-421

Becheikh, N., Landry, R., Armara, N., 2006. Lessons from innovation empirical studies in manufacturing sector: A systematic review of the literature from 1993-2003. Technovation 26, 644-664.

Bernard A.B., Redding S.J., Schott P.K., 2010. Multiple-Product Firms and Product Switching, American Economic Review, American Economic Association, vol. 100(1), pages 70-97, March

Bertrand, M., Schoar A. 2006. The Role of Family in Family Firms. Journal of Economic Perspectives, 20(2): 73-96

Bloom N. Van Reenen J., 2010. Why Do Management Practices Differ across Firms and Countries?, Journal of Economic Perspectives, American Economic Association, vol. 24(1), pages 203-24, Winter

Burgel, O., Fier, A., Licht,G., Murray, G., 2002. The effects of Internationalisation on the rate of growth of High Tech start-ups: evidence for the UK and Germany. in Schätzl, L., \& Revilla Diez, J. (2002). Technological change and regional development in Europe. Contributions to Economics. Heidelberg: Physica-Verlag.

Brown C., Medoff J.L., 2003. Firm age and wages, Volume 21, Issue 3, pp 677-697

Cefis E., Marsili O., 2011, Born to flip. Exit decisions of entrepreneurial firms in high tech and low-tech industries, Journal of Evolutionary Economics, Volume 21, Issue 3, pp 473-498

Chua, J. H., Chrisman, J. J., \& Sharma, P. 2003. Succession and non-succession concerns of family firms and agency relationship with non-family managers. Family Business Review, 16 (2), 89-108.

Chung, K., Lubatkin, M., Rogers, R., \& Owers, J. 1987. Do insiders make better CEOs than outsiders? Academy of Management Executive, 1, 323-329.

Coad A., Guenther C., 2012. Age, diversification and survival in the German machine tool industry, 1953-2002, Papers on Economics and Evolution, n.1123, Max Planck Institute of Economics, Jena, Germany

Coad A., Segarra A., Teruel M. 2013, Like milk or wine: Does firm performance improve with age? Structural Change and Economic Dynamics, 24, pp173-189.

Coad A., Cowling M., Nightingale P., Pellegrino G., Savona M., Siepel J., Innovative Firms and Growth, Department for Business Innovation and Skills, March 2014

Cohen, W.M., Levinthal, D.A., 1990. Absorptive capacity: A new perspective on learning and innovation. Administrative Science Quarterly 35, 128-152. 
Cucculelli M., Ermini B, 2012. New product introduction and product tenure: What effects on firm growth? Research Policy, 41, 808-821

Danneels, E. 2002. The dynamics of product innovation and firm competences. Strategic Management Journal, 23: 1095-1121.

Das, S., 1995. Size, age and firm growth in an infant industry: the computer hardware industry in India. International Journal of Industrial Organization 13, 111-126.

Deeds, D.L., 2001. The role of R\&D intensity, technical development and absorptive capacity in creating entrepreneurial wealth in high technology start-ups. Journal Of Engineering and Technological Management 18, 20-47.

Economides, N., 1996. The economics of networks. International Journal of Industrial Organization 14, 673-699.

Ericson, R., and A. Pakes (1995). "Markov-perfect industry dynamics: A framework for empirical work," The Review of Economic Studies 62 (1), 53-82.

Finkelstein S, Hambrick D.C. and Cannella A.A., 2009. Strategic Leadership: Theory and Research on Executives, Top Management Teams, and Boards, Oxford University Press

Geroski P.A. and Mazzucato M., 2002. Learning and the sources of corporate growth, Industrial and Corporate Change, Oxford University Press, vol. 11(4), pages 623-644, August.

Geroski P.A. 2005. Understanding the implication of empirical work on corporate growth rates, Managerial and Decision Economics, 26: pp129-138

Giulioni G., 2011, The product innovation process and GDP dynamics, Journal of Evolutionary Economics, Volume 21, Issue 4, pp 595-618

Goldberg P.K., Khandelwal A., Pavcnik N., Topalova P., 2009. Multi-product firms and product turnover in the developing world: Evidence from India. NBER working paper no. 14127, National Bureau of Economic Research.

Golder P.N., and Tellis G.J., 2004, Growing, growing, gone: cascade, diffusion and turning point in the product life cycle, Marketing Science, vol23, n.2 Spring, pp 207-218.

Gopalakrishnan, S., Bierly, P.E., 2006. The Impact of Firm Size and Age on Knowledge Strategies During Product Development: A Study of the Drug Delivery Industry. IEEE Transaction on Engineering Manangement 53, 3-16

Grossman G, Shapiro C., (1982), A theory of factor mobility, Journal of Political Economy, 90, 5, 1054-1069.

Hambrick, D. C., and Fukutomi, G. (1991), The seasons of a CEO's tenure, Academy of Management Review, 16: 719-742.

Hambrick, D. C., and Mason, P. A. (1984). Upper echelons: The organization as a reflection of its top managers. The Academy of Management Review, 9 (2), 193-206.

Huergo E., Jaumandreu J., 2004, How does probability of innovation change with firm age? Small Business Economics, 22, 193-207

Johnson, D. K., 2002. The OECD Technology Concordance (OTC): Patents by Industry of Manufacture and Sector of Use, OECD Science, Technology and Industry Working Papers, 2002/5, OECD Publishing.

Jovanovic, B. (1982). Selection and evolution of industry, Econometrica 50(3), 649-670.

Jovanovic, Boyan. 2001. Fitness and Age: Review of Carroll and Hannan's Demography of Corporations and Industries. Journal of Economic Literature, 39(1): 105-119.

Karaevli A., Zajac E.J., 2013. When do outsides CEOs generate strategic change? The enabling role of corporate stability, Journal of Management Studies, 50:7, pp 12671294

Karlsson C., Nystrom K., 2003. Exit and entry over the product life cycle: Evidence from the Swedish manufacturing industry, Small Business Economics, volume 21; pp 135-144

Karniouchina E., Carson S., Short J., Ketchen D.J., 2013. Extending the firm vs industry debate: Does industry life cycle stage matter?, Strategic Management Journal, volume 34; pp 1010-1018

Kirchhoff B.A., 1994. Entrepreneurship and Dynamic Capitalism: The Economics of Business Firm Formation and Growth, Praeger Publishers, Westport CT, USA. 
Klepper, S., Graddy, E. 1990. The evolution of new industries and the determinants of market structure. Rand Journal of Economics 21, 27-44.

Klepper, S., 1996. Entry, exit, growth and innovation over the product life cycle. American Economic Review 86, 562-583.

Klette, T. and S. Kortum. 2004. Innovating firms and aggregate innovation, Journal of Political Economy, 2004.

Krafft J., Ravix J.L., 2008 The firm and its governance along the industry life cycle. In B. Laperche and D. Uzunidis. "Powerful Finance and Innovation Trends in High-Risk Economy", Palgrave MacMillan, pp.131-148.

Krafft J. 2004. Shakeout in industrial dynamics: new developments, new puzzles. In J. Foster and W. Hoelzl. Applied Evolutionary Economics, Edward Elgar, pp.181-196.

Kueng L, Yang M.J., Hong B., 2014, Sources of Firm Life-Cycle Dynamics: Differentiating Size vs. Age Effects, NBER Working Paper No. 20621, October

Kuratko, D. F. and Audretsch, D. B. 2009, Strategic Entrepreneurship: Exploring Different Perspectives of an Emerging Concept. Entrepreneurship Theory and Practice, 33: 1-17.

Le Bas, C. and Poussing, N., 2012, Are Complex Innovators More Persistent than Single Innovators? An Empirical Analysis of Innovation Persistence Drivers. GATE Working Paper No. 1201

Leonard-Barton D. 1992. Core capabilities and core rigidities: a paradox in managing new product development, Strategic Management Journal 13(S1), 111-125.

Levesque M., and M. Minniti 2006. The effect of aging on entrepreneurial behaviour, Journal of Business Venturing 21, 177-194.

Levinthal, D., March J.G. 1993. The Myopia of Learning, Strategic Management Journal Vol 14 95-112

Loof, H., Heshmati, A., 2006. On the Relation between Innovation and Performance: a Sensitivity Analysis. Economics of Innovation and New Technology 15, 317-344.

Malerba F., 2006, Innovation and the evolution of industries, Journal of Evolutionary Economics, April, Volume 16, Issue 1-2, pp 3-23

Marshall, P.J., R. Sorenson, K. Brigham, E. Wieling, A. Reifman, and R. S. Wampler, (2006). "The paradox for the family firm CEO: Owner age relationship to succession-related processes and plans", Journal of Business Venturing 21, 348-368.

McClelland, Patrick L., Xin Liang, and Vincent L. Barker, III. 2010. CEO Commitment to the Status Quo: Replication and Extension Using Content Analysis. Journal of Management 36, no. 5 (September): 1251-1277.

Miller D. 1991. Stale in the Saddle: CEO Tenure and the Match Between Organization and Environment, Management Science, 37, 34-52.

Miller, D., and J. Shamsie J. 2001. Learning across the Life Cycle: Experimentation and Performance among the Hollywood Studio Heads, Strategic Management Journal 22(8), 725-745.

Miller, D., Le Breton-Miller, I., Lester, R., \& Cannella Jr., A. 2007. Are family firms really superior performers? Journal of Corporate Finance, 13(5), 829-858.

Moral, M.J., Jaumandreu, J., 2007. Automobile demand, model cycle and age effects. Spanish Economic Review 9, 193-218.

Penrose, E. T. 1959. The Theory of the Growth of the Firm. New York, John Wiley and Sons

Pfeffer Jand Salancik G., 1978, The External Control of Organizations, Harper \& Row, pp 39-61

Quigley T.J., Hambrick D.C. 2012, When the former CEO stays on as board chair: effects on successor discretion, strategic change and performance, Strategic Management Journal, $33, \mathrm{pp} 834-859$

Reinganum J. 1983. Uncertain innovation and the persistence of monopoly, American Economic Review, 73: 4, 741-748

Rubenson, G.C. and A.K. Gupta. 1996. A Contingency Model of Founder Tenure, Entrepreneurship. Theory and Practice, V. 21, Winter, 21-35 
Schott P.K., 2004. Across-product Versus Within-product Specialization in International Trade, The Quarterly Journal of Economics, MIT Press, vol. 119(2), pages 646-677, May.

Sharma, P., Chrisman, J. J., \& Chua, J. H. 1997. Strategic management of the family business: Past research and future challenges. Family Business Review, 10 (1), 1-35.

Segarra A., Callejon M., 2002. New firms' survival and market turbulence: New evidence from Spain, Review of Industrial Organisation, 20: 1-14

Sorensen, J. and T. Stuart. 2000. Aging, obsolescence and organisational innovation, Administrative Science Quarterly 45, 81-112

Stam E. 2007. Why butterflies don't leave: location behaviour of entrepreneurial firms. Economic Geography, 83 (1), 27-50.

Stinchcombe, A. L. 1965. Social structure and organizations, in J. G. March (ed.), Handbook of Organizations: 142-193. Chicago: Rand McNally

Suits, D., 1984. Dummy variables: mechanics vs. interpretation. Review of Economics and Statistics 66, 177- 180.

Van Praag C.M., 2003. Business Survival and Success of Young Small Business Owners, Small Business Economics, Vol. 21, pp. 1-17.

Villalonga, B., and Amit R. 2006. How do family ownership, control, and management affect firm value? Journal of Financial Economics, 80 (2), 385-417.

Woerter M., 2009, Industry diversity and its impact on the innovation performance of firms, Journal of Evolutionary Economics, Volume 19, Issue 4, pp 675-700

Wu S., Levitas E. and Priem R. L. 2005. CEO Tenure and Company Invention under Differing Levels of Technological Dynamism, The Academy of Management Journal, Vol. 48, No. 5 (Oct.), pp. 859-873

Zhou, K. Z. and Wu, F. 2010. Technological capability, strategic flexibility, and product innovation. Strategic Management Journal, 31: 547-561 
Table 1 - Description of the sample. Number of firms and composition

\begin{tabular}{|c|c|c|c|c|c|}
\hline \multirow{2}{*}{ Variables } & \multicolumn{2}{|c|}{ Sample } & \multirow{2}{*}{ Variables } & \multicolumn{2}{|c|}{ Sample } \\
\hline & $\mathrm{N}^{\circ}$ & $\%$ & & $\mathrm{~N}^{\circ}$ & $\%$ \\
\hline Sectors & & & Size (employees) & & \\
\hline Foods & 78 & 3.6 & $10-19$ & 641 & 29.6 \\
\hline Textile and clothing & 63 & 7.5 & $20-49$ & 1061 & 49.1 \\
\hline Footwear & 74 & 8.0 & $50-99$ & 326 & 15.1 \\
\hline Wood, paper & 70 & 7.9 & $100-249$ & 114 & 5.3 \\
\hline Chemicals, rubber plastic & 68 & 7.8 & $250+$ & 21 & 1.0 \\
\hline Minerals (no metals) & 38 & 6.4 & & & \\
\hline Metalworking & 40 & 20.3 & Firm's starting year & & \\
\hline Mechanical industry & 66 & 16.9 & Before 1970 & 318 & 14.7 \\
\hline Machinery, appliances, vehicle & 37 & 11.0 & 1970-1979 & 656 & 30.3 \\
\hline Furniture, toys, jewels & 29 & 10.6 & 1980-1989 & 734 & 33.9 \\
\hline & & & $1990-$ & 455 & 21.0 \\
\hline & & & Innovative firms by age & & \\
\hline Regions & & & Before 1970 & 297 & 35.6 \\
\hline Veneto & 835 & 38.6 & 1970-1979 & 243 & 29.1 \\
\hline Emilia-Romagna & 661 & 30.6 & 1980-1989 & 183 & 21.9 \\
\hline Marche & 580 & 26.8 & $1990-$ & 110 & 13.2 \\
\hline Abruzzo & 87 & 4.0 & Innovative firms * & 833 & 100.0 \\
\hline Total Sample & 2163 & 100.0 & Total Sample & 2163 & 100.0 \\
\hline
\end{tabular}

Source: Università Politecnica delle Marche

* Firms that have introduced at least one new product in the period 2000-2010 
Figure 1 - Descriptive statistics - Firm's age, product tenure and CEO tenure

Panel A - Firm age distribution in the sample and in the HJ 2004 sample (Huergo E, Jaumandreu J, 2004, How does probability of innovation change with firm age? Small Business Economics, 22, 193-207)
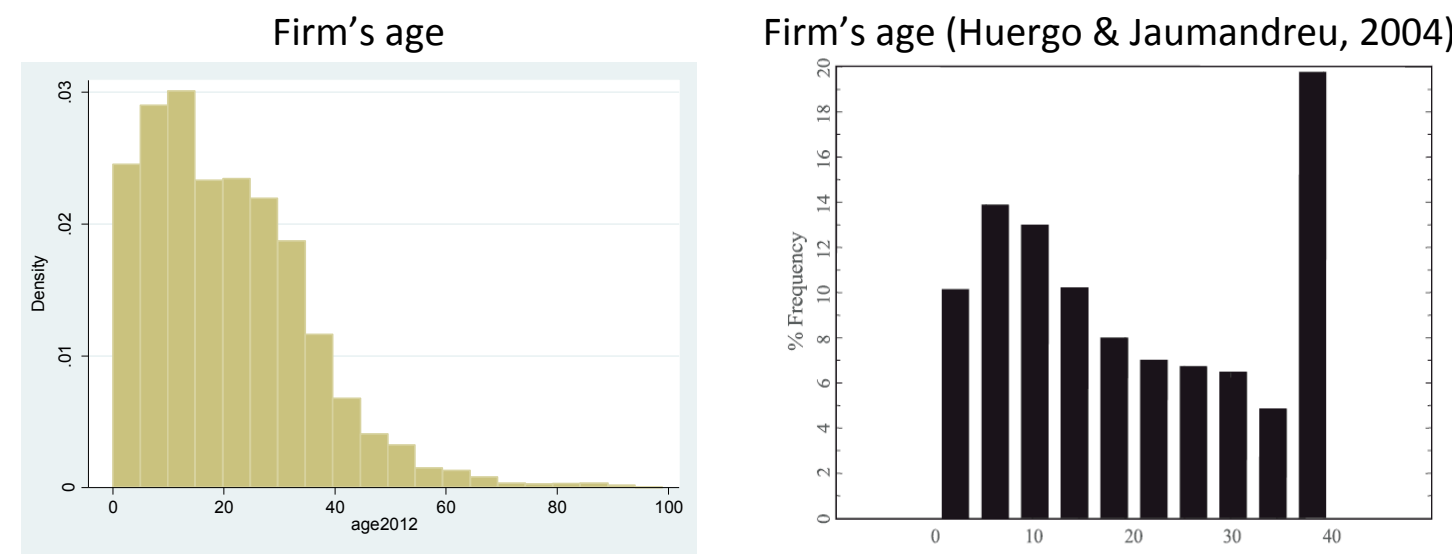

Panel B - Product tenure and CEO tenure

Product tenure

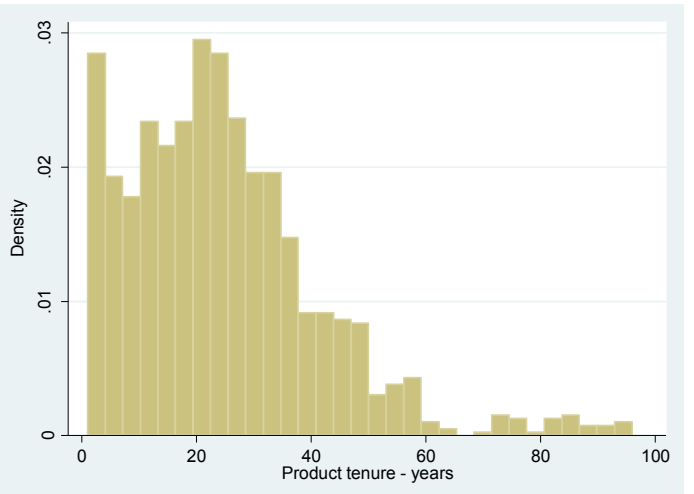

CEO tenure

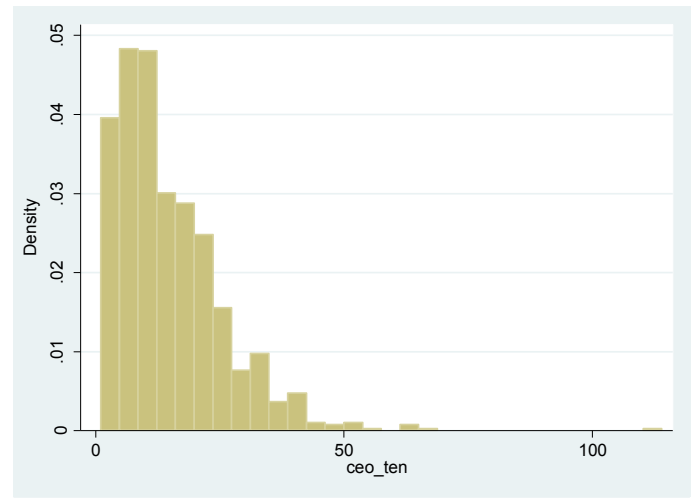


Figure 2 - Descriptive statistics - Innovation propensity by product tenure and CEO tenure

Panel A - Propensity of product introduction ( $y$ axis) and product tenure ( $\mathrm{x}$-axis)

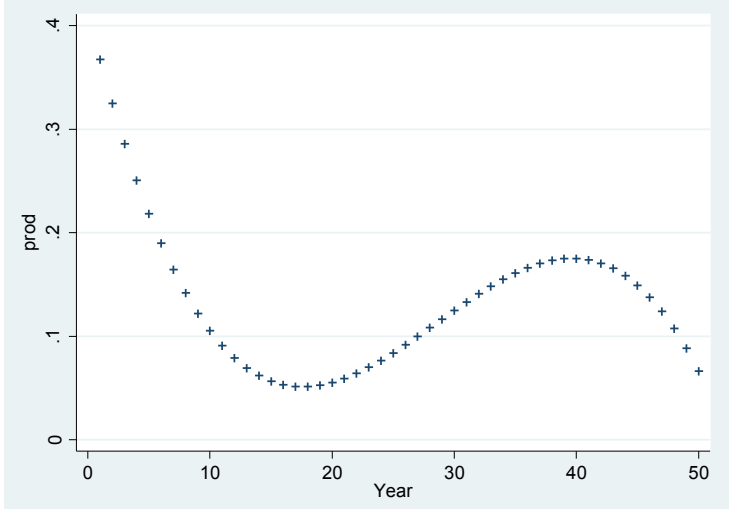

Panel B - Propensity of product introduction ( $\mathrm{y}$ axis) and CEO tenure ( $x$-axis)

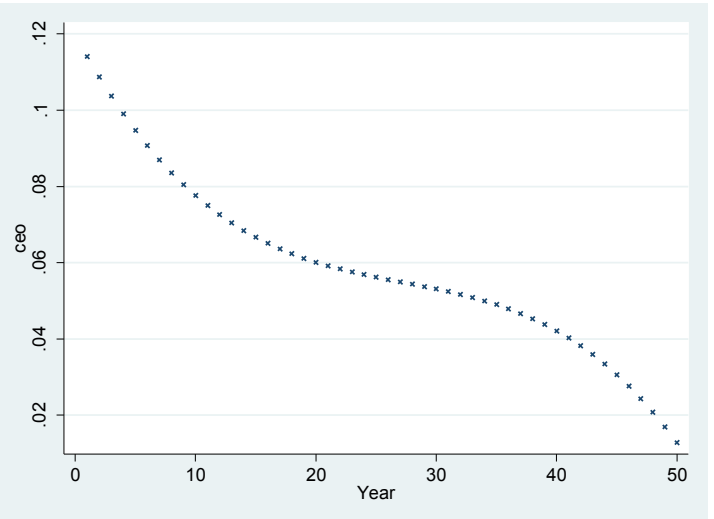


Table 2 - Descriptive statistics of new product introduction by industry lifecycle

\begin{tabular}{lcccc}
\hline Phase * & \multicolumn{2}{c}{ New products } & \multicolumn{2}{c}{ Firm's age } \\
\cline { 2 - 5 } & Mean & sd & Mean & sd \\
& & & & \\
1. Initial low entry & 0.056 & 0.236 & 59 & 32 \\
2. Increasing entry rate & 0.105 & 0.315 & 43 & 9 \\
3. Decreasing rate although still entry & 0.026 & 0.160 & 34 & 18 \\
4. Low entry & 0.020 & 0.140 & 38 & 20 \\
5. Erratic pattern of gross entry & 0.006 & 0.078 & 39 & 18 \\
& & & & 37 \\
Total & 0.023 & 0.150 & 19 \\
\hline
\end{tabular}

* Phases have been obtained following the procedure in Agarwal \& Gort, 2002.

Figure 3 - Product innovation propensity in the industry's lifecycle

0.120

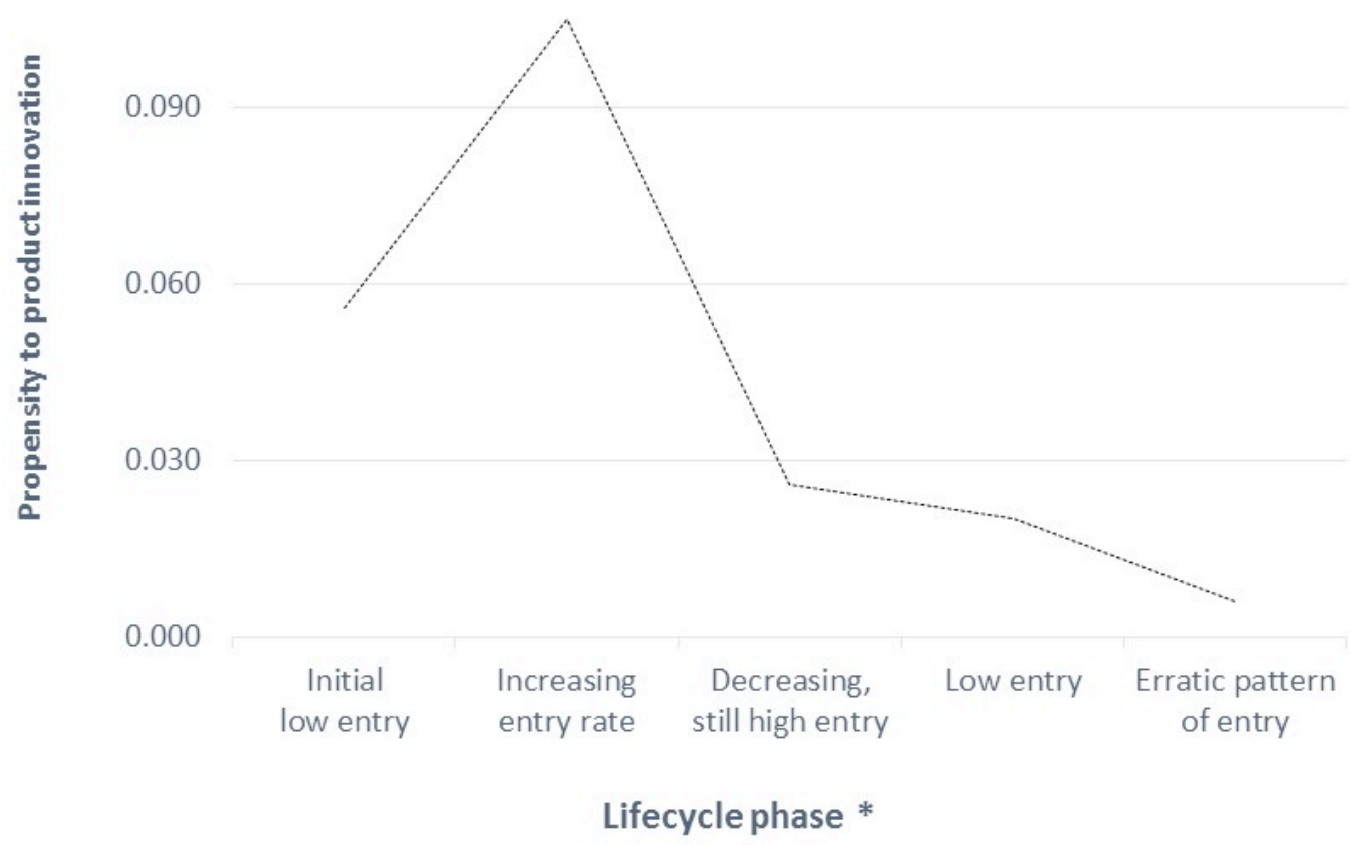


Table 3 - Results from the estimation of model (1) - Control variables $§-2000-2010$

\begin{tabular}{|c|c|c|c|c|c|}
\hline Industry dummies & coeff & se & Time dummies & coeff & se \\
\hline Food and beverage & 0.012 & (0.019) & a2000 & 0.008 & $(0.010)$ \\
\hline Textile & 0.001 & $(0.032)$ & a2001 & $-0.018^{*}$ & (0.010) \\
\hline Clothing & -0.018 & $(0.021)$ & a2002 & $0.012 *$ & (0.010) \\
\hline Leather and Footwear & -0.010 & (0.012) & a2003 & -0.011 & (0.010) \\
\hline Timber and wood products & 0.007 & $(0.025)$ & a2004 & -0.001 & $(0.010)$ \\
\hline Paper products & -0.031 & $(0.028)$ & a2005 & -0.001 & $(0.010)$ \\
\hline Printing & -0.057 & (0.039) & a2006 & 0.004 & $(0.010)$ \\
\hline Chemical products & 0.013 & $(0.032)$ & a2007 & $0.013^{*}$ & (0.010) \\
\hline Rubber and plastic & $0.028 *$ & (0.015) & a2008 & 0.015 & (0.010) \\
\hline Non-metallic minerals & -0.033 & $(0.028)$ & a2009 & -0.024 & $(0.010)$ \\
\hline Metals and other metallic minerals & -0.045 & $(0.032)$ & a2010 & 0.005 & $(0.010)$ \\
\hline Metal products & 0.001 & $(0.012)$ & & & \\
\hline Industrial and agricultural machines & $0.033 * * *$ & $(0.012)$ & Size dummies & & \\
\hline Office and data processing machines & 0.031 & $(0.054)$ & & & \\
\hline Electrical equipments and electronics & -0.001 & $(0.018)$ & Employees: 10_19 & $0.028 *$ & (0.016) \\
\hline Radio, TV, communication machines & -0.024 & (0.029) & Employees: 20_49 & -0.002 & $(0.008)$ \\
\hline Medical, optical machines & -0.040 & $(0.032)$ & Employees: 50_99 & $0.024 * * *$ & (0.006) \\
\hline Vehicles, cars and motors & -0.057 & $(0.038)$ & Employes: 100_249 & 0.004 & $(0.008)$ \\
\hline Other trasportation vehicles & $0.170 * * *$ & $(0.052)$ & Employees: 250_1000 & $-0.055 * * *$ & $(0.015)$ \\
\hline \multirow[t]{2}{*}{ Furniture and miscellanea } & $0.023 * *$ & (0.010) & & & \\
\hline & & & Patents dummy & & \\
\hline \multicolumn{6}{|l|}{ Product dummies } \\
\hline & & & Patents : 0 & $-0.123 * *$ & (0.049) \\
\hline Products: 1 & $-0.033 * * *$ & $(0.011)$ & Patents : 1 & $0.056 * * *$ & (0.020) \\
\hline Products: 2 & $-0.032 * *$ & $(0.014)$ & Patents : 3-5 & 0.021 & (0.015) \\
\hline Products: 3 & $0.027 * *$ & $(0.013)$ & Patents : 6-9 & 0.019 & $(0.016)$ \\
\hline Products: 4 & $0.038^{*}$ & $(0.021)$ & Patents : $10+$ & 0.027 & (0.017) \\
\hline
\end{tabular}

note: $* * * \mathrm{p}<0.01,{ }^{* *} \mathrm{p}<0.05, * \mathrm{p}<0.1$

'Dummy coefficients constrained to add up to zero (Suits, 1984) 
Figure 4 - Innovation propensity by firm's age

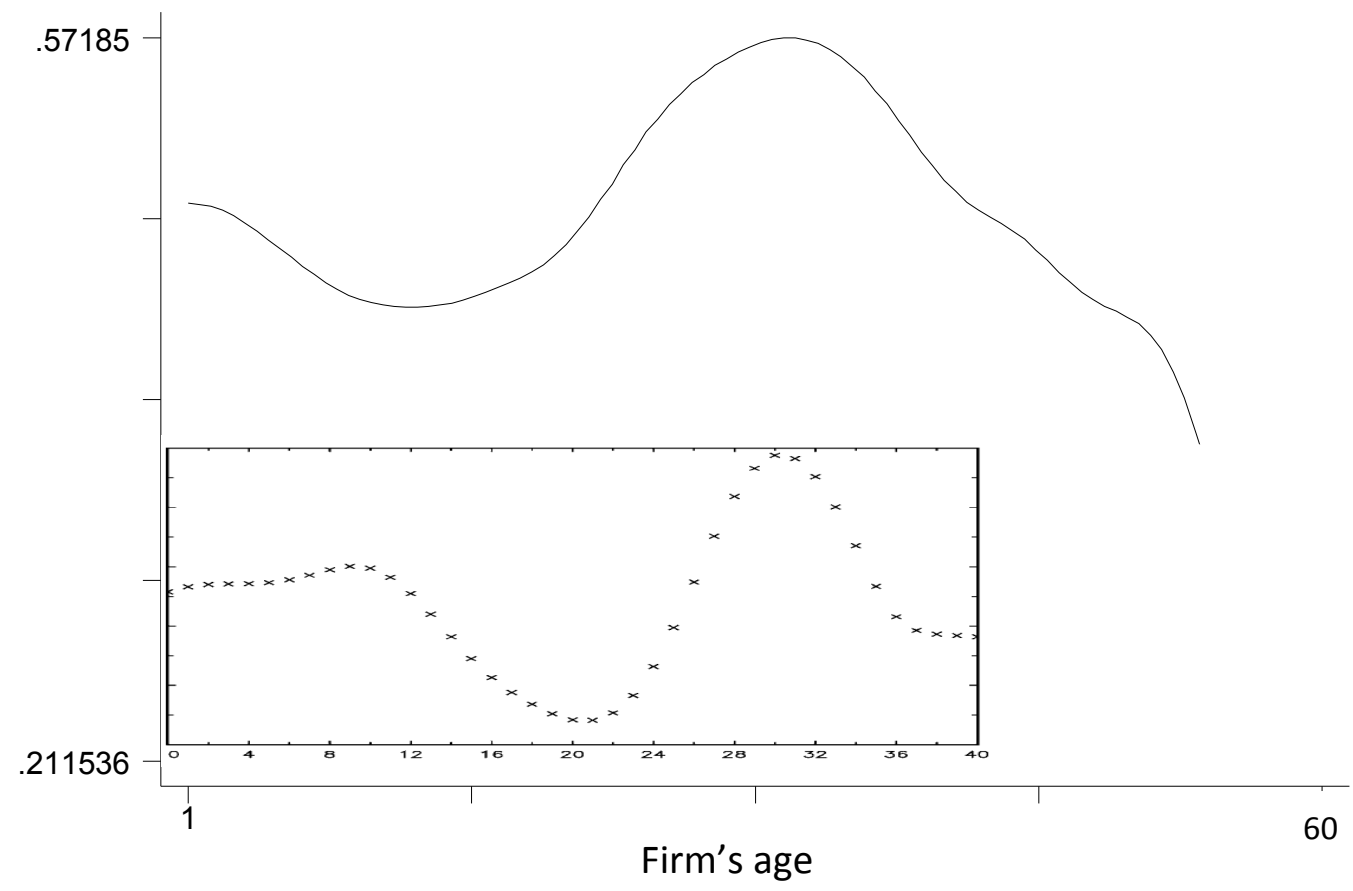


Table 4 - Results from the estimation of model (1) - Main variables and controls 2000-2010.

\begin{tabular}{|c|c|c|c|c|c|c|c|c|c|}
\hline & (1) & (2) & (3) & (4) & (5) & (6) & (7) & (8) & (9) \\
\hline Domestic Turnover Index & $\begin{array}{r}-0.000 \\
(0.000)\end{array}$ & $\begin{array}{r}-0.001 \\
(0.001)\end{array}$ & $\begin{array}{r}-0.000 \\
(0.001)\end{array}$ & $\begin{array}{r}-0.001 \\
(0.001)\end{array}$ & $\begin{array}{r}-0.000 \\
(0.001)\end{array}$ & $\begin{array}{r}-0.000 \\
(0.001)\end{array}$ & $\begin{array}{r}-0.001 \\
(0.001)\end{array}$ & $\begin{array}{r}-0.000 \\
(0.001)\end{array}$ & $\begin{array}{r}0.000 \\
(0.001)\end{array}$ \\
\hline Foreign Turnover Index & $\begin{array}{l}0.001^{*} \\
(0.000)\end{array}$ & $\begin{array}{r}0.001^{* *} \\
(0.001)\end{array}$ & $\begin{array}{r}0.000 \\
(0.001)\end{array}$ & $\begin{array}{r}0.001^{* *} \\
(0.001)\end{array}$ & $\begin{array}{r}0.000 \\
(0.001)\end{array}$ & $\begin{array}{r}0.001 \\
(0.001)\end{array}$ & $\begin{array}{r}0.001 \\
(0.001)\end{array}$ & $\begin{array}{r}0.001^{* *} \\
(0.001)\end{array}$ & $\begin{array}{r}0.001 \\
(0.001)\end{array}$ \\
\hline SOU (Sector of Use) & $\begin{array}{r}0.094 \\
(0.060)\end{array}$ & $\begin{array}{r}-0.055 \\
(0.089)\end{array}$ & $\begin{array}{r}0.006 \\
(0.079)\end{array}$ & $\begin{array}{r}-0.062 \\
(0.091)\end{array}$ & $\begin{array}{r}0.009 \\
(0.081)\end{array}$ & $\begin{array}{l}-0.008 \\
(0.030)\end{array}$ & $\begin{array}{r}-0.028 \\
(0.025)\end{array}$ & $\begin{array}{r}-0.006 \\
(0.023)\end{array}$ & $\begin{array}{r}0.015 \\
(0.027)\end{array}$ \\
\hline IOM (Industry of manufacturing) & $\begin{array}{r}0.020 \\
(0.025)\end{array}$ & $\begin{array}{l}0.051^{*} \\
(0.028)\end{array}$ & $\begin{array}{r}-0.102 \\
(0.111)\end{array}$ & $\begin{array}{l}0.053^{*} \\
(0.024)\end{array}$ & $\begin{array}{l}-0.132 \\
(0.115)\end{array}$ & $\begin{array}{r}0.012 \\
(0.031)\end{array}$ & $\begin{array}{r}0.058^{* *} \\
(0.029)\end{array}$ & $\begin{array}{l}-0.033 \\
(0.022)\end{array}$ & $\begin{array}{r}0.020 \\
(0.024)\end{array}$ \\
\hline Industry lifecycle & $\begin{array}{r}-0.086^{* *} \\
(0.004)\end{array}$ & $\begin{array}{l}-0.021^{*} \\
(0.008)\end{array}$ & $\begin{array}{r}-0.020 \\
(0.018)\end{array}$ & $\begin{array}{l}-0.015^{*} \\
(0.007)\end{array}$ & $\begin{array}{r}-0.014 \\
(0.016)\end{array}$ & $\begin{array}{r}-0.003 \\
(0.017)\end{array}$ & $\begin{array}{r}-0.036^{* *} \\
(0.018)\end{array}$ & $\begin{array}{r}-0.013 \\
(0.012)\end{array}$ & $\begin{array}{r}-0.014 \\
(0.014)\end{array}$ \\
\hline Products (number) & $\begin{array}{r}0.024^{* * *} \\
(0.005)\end{array}$ & $\begin{array}{r}0.039 * * \\
(0.015)\end{array}$ & $\begin{array}{r}-0.031^{* *} \\
(0.015)\end{array}$ & $\begin{array}{r}0.037^{* *} \\
(0.015)\end{array}$ & $\begin{array}{r}-0.032^{* *} \\
(0.015)\end{array}$ & $\begin{array}{r}0.038^{* *} \\
(0.015)\end{array}$ & $\begin{array}{r}-0.029 * * \\
(0.015)\end{array}$ & $\begin{array}{r}-0.033^{* *} \\
(0.014)\end{array}$ & $\begin{array}{r}0.033^{* *} \\
(0.015)\end{array}$ \\
\hline Employees (log) & $\begin{array}{r}-0.012^{* *} \\
(0.005)\end{array}$ & $\begin{array}{r}-0.028^{* *} \\
(0.013)\end{array}$ & $\begin{array}{r}-0.024^{* *} \\
(0.011)\end{array}$ & $\begin{array}{r}-0.027^{* *} \\
(0.013)\end{array}$ & $\begin{array}{r}-0.023^{* *} \\
(0.011)\end{array}$ & $\begin{array}{r}-0.004 \\
(0.016)\end{array}$ & $\begin{array}{r}0.013 \\
(0.015)\end{array}$ & $\begin{array}{r}-0.021^{* *} \\
(0.010)\end{array}$ & $\begin{array}{r}-0.032^{* * *} \\
(0.012)\end{array}$ \\
\hline Patents (Number) & $\begin{array}{r}0.001^{* * *} \\
(0.000)\end{array}$ & $\begin{array}{r}0.001^{* * * *} \\
(0.000)\end{array}$ & $\begin{array}{r}0.001^{* * *} \\
(0.000)\end{array}$ & $\begin{array}{r}0.001^{* * *} \\
(0.000)\end{array}$ & $\begin{array}{r}0.001^{* * *} \\
(0.000)\end{array}$ & $\begin{array}{r}0.001^{* * *} \\
(0.000)\end{array}$ & $\begin{array}{r}0.001 * * * \\
(0.000)\end{array}$ & $\begin{array}{r}0.001^{* * *} \\
(0.000)\end{array}$ & $\begin{array}{r}0.001^{* * *} \\
(0.000)\end{array}$ \\
\hline Firm age (log) & $\begin{array}{l}-0.008 \\
(0.009)\end{array}$ & & & & & & & & \\
\hline Firm age $(<10)$ & & & & & & $\begin{array}{l}0.073^{* *} \\
(0.032)\end{array}$ & $\begin{array}{r}0.009 \\
(0.028)\end{array}$ & & \\
\hline Firm age (10-19) & & $\begin{array}{l}-0.125^{*} \\
(0.064)\end{array}$ & $\begin{array}{r}0.017 \\
(0.058)\end{array}$ & $\begin{array}{r}0.020 \\
(0.053)\end{array}$ & $\begin{array}{r}0.022 \\
(0.050)\end{array}$ & $\begin{array}{l}-0.058^{*} \\
(0.031)\end{array}$ & $\begin{array}{r}-0.088^{* *} \\
(0.026)\end{array}$ & & \\
\hline Firm age (20-39) & & $\begin{array}{r}-0.085 \\
(0.060)\end{array}$ & $\begin{array}{l}0.130 * * \\
(0.055)\end{array}$ & $\begin{array}{l}0.015^{*} \\
(0.007)\end{array}$ & $\begin{array}{r}0.129 * * \\
(0.058)\end{array}$ & $\begin{array}{r}-0.009 \\
(0.021)\end{array}$ & $\begin{array}{r}0.052^{* * *} \\
(0.019)\end{array}$ & & \\
\hline Firm age $(40+)$ & & $\begin{array}{l}-0.111^{*} \\
(0.061)\end{array}$ & $\begin{array}{c}0.109^{*} \\
(0.056)\end{array}$ & $\begin{array}{r}-0.123^{* *} \\
(0.063)\end{array}$ & $\begin{array}{c}0.106^{*} \\
(0.054)\end{array}$ & $\begin{array}{r}-0.006 \\
(0.021)\end{array}$ & $\begin{array}{r}0.028^{* *} \\
(0.012)\end{array}$ & & \\
\hline Product tenure $(\log )$ & & & $\begin{array}{r}-0.156^{* * *} \\
(0.004)\end{array}$ & & $\begin{array}{r}-0.157^{* * *} \\
(0.014)\end{array}$ & & $\begin{array}{r}-0.167^{* * *} \\
(0.019)\end{array}$ & $\begin{array}{r}-0.145^{* * *} \\
(0.009)\end{array}$ & \\
\hline Product tenure sq. (log) & & & $\begin{array}{c}0.004^{*} \\
(0.002)\end{array}$ & & $\begin{array}{r}0.000 \\
(0.003)\end{array}$ & & $\begin{array}{r}0.002 \\
(0.003)\end{array}$ & $\begin{array}{c}0.003^{*} \\
(0.002)\end{array}$ & \\
\hline CEO tenure (log) & & & & $\begin{array}{l}-0.396^{*} \\
(0.190)\end{array}$ & $\begin{array}{r}-0.290 \\
(0.223)\end{array}$ & & $\begin{array}{r}0.212 \\
(0.339)\end{array}$ & & $\begin{array}{l}-0.174^{*} \\
(0.096)\end{array}$ \\
\hline CEO tenure sq. $(\log )$ & & & & $\begin{array}{r}0.065 \\
(0.042)\end{array}$ & $\begin{array}{r}0.046 \\
(0.037)\end{array}$ & & $\begin{array}{r}0.119 \\
(0.134)\end{array}$ & & $\begin{array}{c}0.028^{*} \\
(0.016)\end{array}$ \\
\hline Firm age: $(0,10)$ & & & & & & & & $\begin{array}{c}-0.024^{*} \\
(0.013)\end{array}$ & $\begin{array}{r}-0.055^{* * *} \\
(0.014)\end{array}$ \\
\hline Firm age: $(10,20)$ & & & & & & & & $\begin{array}{r}0.012^{* * *} \\
(0.002)\end{array}$ & $\begin{array}{l}0.004^{*} \\
(0.003)\end{array}$ \\
\hline Firm age: $(20,40)$ & & & & & & & & $\begin{array}{r}0.003^{* * *} \\
(0.001)\end{array}$ & $\begin{array}{r}-0.001 \\
(0.001)\end{array}$ \\
\hline Firm age: $(40+)$ & & & & & & & & $\begin{array}{r}0.001^{* * *} \\
(0.000)\end{array}$ & $\begin{array}{r}-0.000 \\
(0.000)\end{array}$ \\
\hline _cons & $\begin{array}{r}0.039 \\
(0.078)\end{array}$ & $\begin{array}{r}0.152 \\
(0.154)\end{array}$ & $\begin{array}{r}0.613^{* * *} \\
(0.140)\end{array}$ & $\begin{array}{l}0.951^{*} \\
(0.571)\end{array}$ & $\begin{array}{r}1.056^{* * * *} \\
(0.354)\end{array}$ & - & - & $\begin{array}{r}0.783^{* * *} \\
(0.250)\end{array}$ & $\begin{array}{r}1.245^{* * *} \\
(0.413)\end{array}$ \\
\hline Number of observations & 1,850 & 1,820 & 1,722 & 1,718 & 1,718 & 1,710 & 1,710 & 1,718 & 1,718 \\
\hline Adjusted R2 & 0.043 & 0.024 & 0.245 & 0.023 & 0.246 & 0.185 & 0.026 & 0.249 & 0.025 \\
\hline
\end{tabular}

note: ${ }^{* * *} p<0.01, * * p<0.05, * p<0.1-$ Controls: year, 3-digit industry. Columns $1-5$ are OLS estimate. Dummy coefficients for a firm's age reported in columns 6 and 7 are constrained to add up to zero (Suits, 1984). Column 8 and 9 report spline function models with age knots set at 10, 20 and 40. 
Table 5 - Results from the estimation of the model linking product innovation to the time (years) elapsed since the last CEO change, by type of change (family vs external)

\begin{tabular}{|l|r|r|r|r|r|r|}
\hline Inno = New product introduction & $\begin{array}{r}\text { Total CEO } \\
\text { changes }\end{array}$ & & Family & new-CEO & External & new-CEO \\
\hline Inno 1 year after succession & & & & & & \\
\hline Inno 2 years after succession & $-0.287^{* *}$ & $(0.143)$ & $-0.361^{*}$ & $(0.192)$ & -0.539 & $(0.423)$ \\
\hline Inno 3 years after succession & 0.106 & $(0.068)$ & 0.088 & $(0.087)$ & $0.362^{* *}$ & $(0.153)$ \\
\hline Inno 4 years after succession & $0.138^{*}$ & $(0.075)$ & 0.132 & $(0.091)$ & $0.359^{* *}$ & $(0.152)$ \\
\hline Inno 5 years after succession & 0.044 & $(0.077)$ & 0.014 & $(0.101)$ & $0.384^{* *}$ & $(0.178)$ \\
\hline Inno 6 years after succession & 0.022 & $(0.081)$ & 0.040 & $(0.114)$ & 0.176 & $(0.168)$ \\
\hline Inno 7 years after succession & 0.064 & $(0.065)$ & $0.137^{*}$ & $(0.073)$ & -0.014 & $(0.167)$ \\
\hline Inno 8 years after succession & -0.073 & $(0.070)$ & 0.015 & $(0.083)$ & -0.114 & $(0.159)$ \\
\hline Inno 9 years after succession & 0.035 & $(0.095)$ & -0.041 & $(0.117)$ & -0.492 & $(0.258)$ \\
\hline Inno 10 years after succession & -0.049 & $(0.079)$ & -0.021 & $(0.095)$ & -0.097 & $(0.210)$ \\
\hline Firm age & -0.035 & $(0.089)$ & -0.002 & $(0.098)$ & -0.025 & $(0.160)$ \\
\hline Firm size (employees) & $0.008^{* * *}$ & $(0.001)$ & $0.007^{* * *}$ & $(0.001)$ & $0.009^{* * *}$ & $(0.002)$ \\
\hline Constant & -0.000 & $(0.000)$ & -0.000 & $(0.000)$ & -0.001 & $(0.001)$ \\
\hline Number of observations & - & & & - & & - \\
\hline note: *** $p<0.01{ }^{* *} p<0.05{ }^{*} p<0.1$ & 829 & & & 458 & & 371 \\
\hline
\end{tabular}

note: ${ }^{* \star *} p<0.01,{ }^{* *} p<0.05,{ }^{*} p<0.1$

Includes: year , industry, patents and product dummies. The coefficient sets are constrained to add to zero (Suits, 1984)

Figure 6 - Probability of product innovation and the succession-innovation gap External new CEOs (Panel A) and family new CEOs (Panel B)

External new CEOs

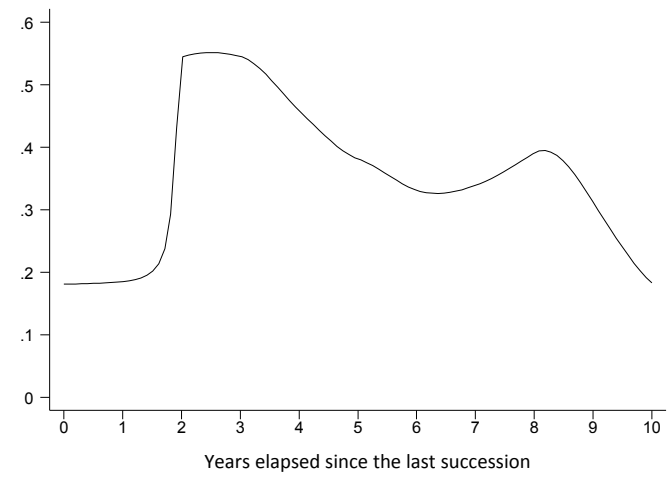

Family new CEOs

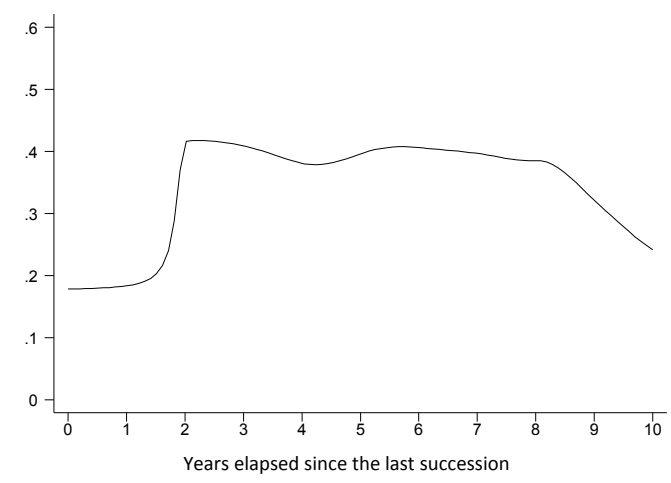




\section{Appendix}

\section{Table A1 - Description of the variables}

Variables Description

1. New product

2. Firm age (log)

3. Product tenure

4. CEO tenure

5. SOU

6. IOM

7. Domestic Turnover Index

8. Foreign Turnover Index

9. \# Products

10. Employees ( $\log )$

11. Patents

12. Industry lifecycle
New products introduction (dummy)

Firm age (log)

Number of years between the current year " $\mathrm{t}$ " and the year " $\mathrm{t}$ " of introduction of the last product entered in firm product portfolio, with $\mathrm{t}^{*}<\mathrm{t}(\log )$

Number of years between the current year " $t$ " and the year " $t$ " of the last CEO hiring, with $t^{*}<t(\log )$

Sectors intensely using patents produced by other sectors (Johnson, 2002).

Sectors with patenting rate larger than the median score of the total industry distribution (patent-producing sectors) (Johnson, 2002)

Eurostat business cycle indicator, showing the evolution of the market for goods and services in the domestic industrial sector. The industry breakdown is by 1013 -digit NACE sectors.

Eurostat business cycle indicator, showing the evolution of the market for goods and services in the foreign industrial sector. The industry breakdown is by 1013 -digit NACE sectors.

Number of products in the company's portfolio Number of employees (log)

Number of patents

Index of industry lifecycle computed using data on entry and exit in the Italian manufacturing industry, for the period 1995-2010. A total of 22 Nace 2-digit sectors have been considered. The phases have been identified as those time intervals for which the Agarwal and Gort (2002) definition applies, with phases being delineated on the basis of the gross entry rate per year. 
Table A2 - Descriptive statistics and correlations.

\begin{tabular}{|c|c|c|c|c|c|c|c|c|c|c|c|c|c|c|c|c|c|c|}
\hline & Variable & Mean & p50 & Min & $\operatorname{Max}$ & S.D. & 1 & 2 & 3 & 4 & 5 & 6 & 7 & 8 & 9 & 10 & 11 & 12 \\
\hline 1 & New product & 0.023 & 0 & 0 & 1 & 0.151 & 1 & & & & & & & & & & & \\
\hline 2 & Firm age (year) & 36.5 & 34 & 7 & 125 & 18.7 & -0.034 & 1 & & & & & & & & & & \\
\hline 3 & Product tenure (year) & 24.9 & 22.5 & 1 & 125 & 17.9 & $-0.1911^{*}$ & $0.4390 *$ & 1 & & & & & & & & & \\
\hline 4 & CEO tenure (year) & 27.6 & 29 & 7 & 58 & 12.9 & -0.045 & 0.026 & $0.1095^{*}$ & 1 & & & & & & & & \\
\hline 5 & SOU Sector of Use & 0.221 & 0 & 0 & 1 & 0.415 & 0.042 & $0.0782^{*}$ & -0.033 & 0.055 & 1 & & & & & & & \\
\hline 6 & IOM Industry of Manuf. & 0.611 & 1 & 0 & 1 & 0.488 & 0.071 & $-0.2026^{*}$ & $-0.3233^{*}$ & 0.028 & $0.3442^{*}$ & 1 & & & & & & \\
\hline 7 & Domestic Turn. Index & 102.1 & 100 & 49.7 & 163.9 & 11.8 & 0.014 & $0.0873^{*}$ & 0.009 & -0.059 & $-0.0845 *$ & $-0.0929 *$ & 1 & & & & & \\
\hline 8 & Foreign Turn. Index & 104.3 & 100 & 21.1 & 219.6 & 21.1 & 0.042 & -0.037 & $-0.1281^{*}$ & 0.012 & $0.0891 *$ & $0.1926^{*}$ & $0.4182^{*}$ & 1 & & & & \\
\hline 9 & Products (number) & 1.8 & 1 & 1 & 4 & 0.972 & $0.1662^{*}$ & 0.046 & $-0.3837 *$ & $-0.0857^{*}$ & 0.068 & $0.1490 *$ & 0.064 & $0.1725^{*}$ & 1 & & & \\
\hline 10 & Employees & 96.5 & 67 & 1 & 975 & 109 & -0.039 & $0.0995 *$ & 0.057 & 0.033 & 0.026 & $-0.1070^{*}$ & 0.021 & 0.026 & $0.0925 *$ & 1 & & \\
\hline 11 & Patents & 6.8 & 1 & 0 & 200 & 21.9 & 0.052 & 0.007 & -0.064 & $-0.1202^{*}$ & -0.004 & 0.046 & 0.002 & $0.1123^{*}$ & 0.077 & $0.1631^{*}$ & 1 & \\
\hline 12 & Industry lifecycle & 3.5 & 3 & 1 & 5 & 0.784 & -0.064 & 0.026 & $0.1844^{*}$ & $0.0839 *$ & $-0.1463^{*}$ & $-0.4536^{*}$ & $-0.1201^{*}$ & $-0.3434 *$ & $-0.1955^{*}$ & 0.030 & $-0.1231 *$ & 1 \\
\hline
\end{tabular}

* Significant at $1 \%$ 
Table A3 - Robustness of innovation propensity to different industry controls ${ }^{\circ}$

\begin{tabular}{|c|c|c|c|c|c|}
\hline Variables & 1 & 2 & 3 & 4 & 5 \\
\hline \multirow[t]{2}{*}{ Firm's age (10-19 yrs) } & -0.003 & 0.023 & 0.083 & 0.092 & -0.009 \\
\hline & $(0.057)$ & $(0.058)$ & $(0.062)$ & $(0.062)$ & $(0.033)$ \\
\hline \multirow[t]{2}{*}{ Firm's age (20-39 yrs) } & $0.099 *$ & $0.129 * *$ & $0.179 * * *$ & $0.176 * * *$ & $0.086 * * *$ \\
\hline & $(0.056)$ & $(0.058)$ & $(0.063)$ & $(0.068)$ & $(0.021)$ \\
\hline \multirow[t]{2}{*}{ Firm's age $(40+y r s)$} & 0.093 & $0.106 *$ & $0.150 * *$ & $0.142 * *$ & $0.061^{*}$ \\
\hline & $(0.057)$ & $(0.058)$ & $(0.061)$ & $(0.062)$ & $(0.027)$ \\
\hline \multirow{2}{*}{ Industry } & \multirow{2}{*}{ Pavitt(a) } & $O E C D$ & NACE & $N A C E$ & SoU/ \\
\hline & & Technology (b) & 3-dig. & 4-dig. & $\operatorname{loM}(c)$ \\
\hline \multirow[t]{2}{*}{ Constant } & $0.491^{*}$ & $1.001^{* * *}$ & $1.551 * * *$ & $1.557^{* * *}$ & $0.468 * * *$ \\
\hline & $(0.286)$ & $(0.348)$ & $(0.424)$ & $(0.500)$ & (0.135) \\
\hline Adjusted R2 & 0.241 & 0.246 & 0.282 & 0.322 & 0.242 \\
\hline
\end{tabular}

${ }^{\circ}$ OLS regressions of new product introduction on industry controls. Only year dummies included. Note: ${ }^{* * *} \mathrm{p}<0.01, * * \mathrm{p}<0.05, * \mathrm{p}<0.1$

(a) Pavitt, K. (1984). Sectoral patterns of technical change: towards a taxonomy and a theory. Research Policy. 13: 343-373.

(b) OECD, 2011, ISIC REV. 3 Technology Intensity Definition. Classification of manufacturing industries into categories based on R\&D intensities, OECD Directorate for Science, Technology and Industry, Economic Analysis and Statistics Division, 7 July, 2011.

(c) Johnson, D. K., 2002. The OECD Technology Concordance (OTC): Patents by Industry of Manufacture and Sector of Use, OECD Science, Technology and Industry Working Papers, 2002/5, OECD Publishing. 